Elaine Jeffreys (2018) 'Public Policy and LGBT People and Activism in Mainland China', in W. Lam (ed.) Routledge Handbook of the Chinese Communist Party, Abingdon: Routledge, pp. 283-96.

ISBN: 9781138684430. (Author Copy: 22 January 2017)

\title{
Public Policy and LGBT People and Activism in Mainland China
}

\author{
Elaine Jeffreys \\ University of Technology Sydney
}

This chapter looks at the lack of explicit public policies relating to lesbian, gay, bisexual and transgender (LGBT) people in the People's Republic of China (PRC), and recent events and activist efforts that highlight or challenge that omission. Although the term LGBT does not specify the full range of sexual and gender non-conforming people, it is used in this chapter as a short-hand to represent all sexual and gender minorities, in part because other possible terms such as 'queer' also reference western academic theories, and do not have the same significance in China. The term 'PRC' is used to refer to post-1949 mainland China. The chapter does not examine the evolution of LGBT-related policies in Hong Kong and Macau, which have different histories of social organization and LGBT activism (Engebretson, Schroeder and Bao 2015; Kam 2013; Kong 2010; Yau 2010).

While the movement for equality for LGBT people in western liberal-democratic societies has been pronounced 'one of the most successful in recent history', the state of LGBT rights in China is described as 'lousy' with grim prospects for LGBT people and organizations (Hong 2015). Such pessimism is associated with the authoritarian nature of the Communist Party-state and its historical failure to acknowledge individual and sexual rights, as demonstrated by the absence of national legislation to empower LGBT people. In December 2013, however, the PRC government accepted recommendations at the Human Rights Council of the United Nations (UN) that it establish anti-discrimination legislation to ensure that LGBT people enjoy equal treatment, and prohibit workplace discrimination based on sexual orientation and gender identity (United Nations General Assembly 2013). This has encouraged various LGBT individuals to file a series of landmark legal cases with the 
Elaine Jeffreys (2018) 'Public Policy and LGBT People and Activism in Mainland China', in W. Lam (ed.) Routledge Handbook of the Chinese Communist Party, Abingdon: Routledge, pp. 283-96.

ISBN: 9781138684430. (Author Copy: 22 January 2017)

Chinese courts against different government departments to oppose discrimination and demand affirmative legislation. Many of these cases are managed by a loose affiliation of volunteers known as the 'Rainbow Lawyers' - the rainbow is an international symbol of gay pride (Fan 2016). These efforts simultaneously highlight the emergence of an LGBT movement in China and provide a basis for domestic critique of government inaction, especially given President Xi Jinping's oft-expressed commitment to enhancing rule by law (Liebman 2014: 97).

The chapter contextualizes the emergence of LGBT activism in mainland China by first defining some key terms and explaining the historical lack of attention to LGBT issues in the PRC. It then explains how the development of LGBT communities, and advocacy groups, have been and are constrained by Party-state censorship of media and controls over civil sector organizations, even though homosexuality is not criminalized in Chinese law. Finally, the chapter highlights some key areas of LGBT activism in China and the associated challenges.

\section{Background and key terms}

In most western societies, it is unlawful to discriminate against or treat another person less favourably on the basis of their sexual orientation or gender identity than someone without that attribute would be treated in the same or similar circumstances (Australian Human Rights Commission 2013). Sexual orientation means a person's sexual orientation towards persons of the same sex, a different sex, or the same sex and a different sex. Common terms that are used to describe a person's sexual orientation include heterosexual/straight, homosexual, lesbian, gay and bisexual. Gender identity means the gender-related identity, appearance or mannerisms or other gender-related characteristics of a person, including how a person presents their gender which may be an identity that is neither male nor female (Ibid.). Terms used to describe a person's gender identity include transgender, trans and gender diverse. Despite policy advances, inequality and prejudice persist in relation to LGBT people and there are lawful exceptions to anti-discrimination laws. Same-sex marriage is not legal in all western countries, although same-sex partnerships usually have legal protections, and the Catholic Church is permitted to employ men only as priests. 
Elaine Jeffreys (2018) 'Public Policy and LGBT People and Activism in Mainland China', in W. Lam (ed.) Routledge Handbook of the Chinese Communist Party, Abingdon: Routledge, pp. 283-96.

ISBN: 9781138684430. (Author Copy: 22 January 2017)

In China, there are no protective national laws and there is no national political discourse on LGBT matters; moreover, no specific Ministry or government department has responsibility for issues relating to sexual orientation and gender identity (UNDP, USAID 2014: 11). This situation, in conjunction with political controls on civil sector organizations and media censorship of sex-related content, has limited the development of LGBT culture and expression, and public discussion and advocacy on LGBT matters.

The absence of LGBT policies in mainland China reflects the historical 'invisibility' of LGBT people, organizations and advocacy until recently. One way of highlighting the newness of the term 'LGBT' more generally is to note that it was only included in the online Oxford English Dictionary in 2006, although the draft entry for the term indicates that it was used in a gay magazine in the early 1990s. LGBT communities and organizations have developed a strong public profile in western societies since the first major gay liberation march was held in New York in 1970. However, there is little documentation about or evidence of gay and lesbian communities in the PRC until the 1990s.

Following the founding of the PRC under the leadership of the Communist Party in 1949, state control of industry and allocation of resources removed the space for public discussions and expressions of sex and sexuality until after the introduction of market-based economic reforms in December 1978 (Jeffreys 2012: 2-3). During the Mao era (1949-1976), most urban Chinese spent their entire lives in the closed community of a socialist work-unit and rural agricultural producers became tied to their place of birth because the state allocated jobs, housing and social services, and therefore needed to know the identity and location of its workers. Everyday life was organized around work and collectivist political movements, and public venues were highly restricted in number until the opening-up of the country's hospitality and service industries in the late 1980s. This situation, combined with both the importance placed in Chinese culture on marriage for procreation and the establishment of a state-controlled media, literally eliminated the space for public discussions of sexual orientation and identity.

LGBT people are now a visible feature of life in the PRC, as demonstrated by the publicized release of a letter from over 190 organizations across China condemning violence based on sexual orientation, after a gunman killed 49 people in a gay nightclub in the USA in 2016 
Elaine Jeffreys (2018) 'Public Policy and LGBT People and Activism in Mainland China', in W. Lam (ed.) Routledge Handbook of the Chinese Communist Party, Abingdon: Routledge, pp. 283-96.

ISBN: 9781138684430. (Author Copy: 22 January 2017)

(Bai 2016). The letter added that LGBT people in China experience unacceptable violence and discrimination, as evidenced by the existence of 'gay conversion therapy' and schoolyard bullying of LGBT youth. As this action suggests, LGBT people are marginalized in the PRC, but they are no longer invisible or voiceless.

The growth of LGBT-friendly websites and social media since the 2000s has provided expanded means of communication and socialization for gays and lesbians, and to a lesser extent for bisexual and transgender people (UNDP, USAID 2014: 12). Large and mediumsized cities now have bars and cafés that are frequented by young urban gays and lesbians, and low- and high-end bathhouses that are patronized by older men who have sex with men but who may not self-identify as homosexual (Jeffreys and Yu 2015: 75-6). LGBT organizations can also be found in numerous cities, with organizations such as the Chinese Lala [Lesbian] Alliance holding networking, capacity building and advocacy training camps in different cities since 2007 (UNDP, USAID 2014: 50).

In 2015, Jin Xing, once China's best male dancer while performing with the People's Liberation Army troupe, and now an internationally acclaimed dancer and the married mother of three adopted children, started hosting her own television talk show, after a popular stint as a 'hard' judge on China's So You Think You Can Dance (Jin Xing tuokou xiu 2015). Widespread public interest in Jin's life story has opened the space for discussions of transgender people. However, her life is typically presented in the media in terms of gender conformity - the struggle of a woman trapped in a man's body to become her true self and realise her dreams - rather than challenging the male/female gender binary (Davies and Davies 2010). Her parents' acceptance of her decision to have sex reassignment surgery and her public, rich and glamorous lifestyle also stand in marked contrast to the lives of most transgender people in China who cannot afford costly hormone replacement therapy and surgery, which are difficult to access through the state-funded health care system (UNDP, USAID 2014: 7).

Along with their growing visibility, new terms have emerged to describe LGBT people in China. The most common words used to describe same-sex attracted people are: 'tongxinglian' (same-sex love), a term that is now primarily used by older married men who have sex with men; 'tongzhi' (comrade), an appropriation of Chinese revolutionary modes of 
Elaine Jeffreys (2018) 'Public Policy and LGBT People and Activism in Mainland China', in W. Lam (ed.) Routledge Handbook of the Chinese Communist Party, Abingdon: Routledge, pp. 283-96.

ISBN: 9781138684430. (Author Copy: 22 January 2017)

address that entered mainland China in the 1990s from Hong Kong-based homosexual activist groups and is now used in ways that are comparable with the English word LGBT; and the English term 'gay', which gestures towards identification with global 'gayness' (Jeffreys and Yu 2015: 76-7). Same-sex attracted women are often referred to as 'lala' or 'lesi' (both transliterations of 'les/lesbian') or 'lily' (baihe, borrowed from Japanese anime and games). The Chinese term ' $k u$ 'er' is a homophone for 'queer', which similarly refers to a range of non-heteronormative sexualities and subjectivities, but translates as 'cool'. It has been adopted as a marker of social distinction by alternative artists, film-makers and academics (Ibid.: 78). The Chinese term for bisexual (shuangxinglianzhe) is a transliteration from English that is unfamiliar to most mainland Chinese (Chou 2000: 42). A 2014 UNaffiliated report on being LGBT in Asia notes that public perceptions of transgender phenomenon in the PRC refer to persons who have undergone a sex change (bianxingren), rather than persons who transgress gender boundaries (kuaxingbie), which is a term that is mainly used only by activists (UNDP, USAID 2014: 28, n35).

The PRC now also has LGBT festivals, which are designed to celebrate LGBT people and raise public awareness of LGBT issues. In 2016, the winner of the first Mr Gay China competition, a franchise from the international pageant Mr Gay World, described the event as 'a great platform to raise awareness of the LGBT community' (Roxburgh 2016). A 2009 article in the China Daily, a state-run English-language newspaper, similarly praised the PRC's first mass LGBT event - ShanghaiPride - for showcasing the country's social progress and raising public awareness of China's gay community ('Pride of tolerance' 2009: $8)$.

But people who wish to live openly as LGBT still face considerable obstacles. ShanghaiPride is typically run as a film and art festival, rather than as a street march, to avoid difficulties associated with obtaining a license for a march from police. Media censors have banned certain films from being screened at ShanghaiPride, and queer film festivals organized in Beijing since 2001 have been variously stopped by police or held in 'secret' locations (Hamer 2014). Although LGBT organizations have run gay culture festivals in north-eastern China since 2011, the organizer of a gay march in Hunan Province in 2013 was detained for failing to obtain permission to hold the event ('Changsha' 2013; UNDP, USAID 2014: 48). There is limited information on LGBT activities in rural and western regions of China, and a survey of 
Elaine Jeffreys (2018) 'Public Policy and LGBT People and Activism in Mainland China', in W. Lam (ed.) Routledge Handbook of the Chinese Communist Party, Abingdon: Routledge, pp. 283-96.

ISBN: 9781138684430. (Author Copy: 22 January 2017)

some of the 27 million users on a Chinese gay dating application suggests that fewer than 5 per cent of the respondents were 'out' (Roxburgh 2016; UNDP, USAID 2014: 12).

The term LGBT therefore applies to people of diverse ages and socio-economic, cultural, religious and ethnic backgrounds who may experience being homosexual, gay, lesbian, bisexual and transgender, in different ways in different parts of China, with access to LGBT support networks and levels of public acceptance generally diminishing with the size of the city.

\section{Law, science, society and censorship}

In western societies, the three main goals of the push to obtain legal rights for LGBT people has been decriminalization, anti-discrimination legislation and legal recognition for same-sex partnerships respectively (UNDP, USAID 2014: 23). In the UK, for example, consensual and private homosexual acts between two men aged over 21 years were decriminalized in England and Wales in 1967 and in Scotland and Northern Ireland in the early 1980s (Bedell 2007). Homosexual sex was previously treated as an act of gross indecency, resulting in the arbitrary arrest of many homosexual men. The first gay march in the UK took place in London in 1971. The age of consent for consensual homosexual sex was lowered from 21 years to 18 years in 1994 and to 16 years in 2001 (16 is the age of consent for heterosexual sex in the UK). The British government lifted bans on lesbians and gays in the armed forces in 2000 and the first civil partnerships between homosexuals took place in 2005 (Ibid.).

The Criminal Law of the PRC (1997), which was first issued in 1979 and revised in 1997 , does not directly criminalize homosexuality. It prohibits violent and non-consensual sex acts, such as rape, sexual assault, forced prostitution and sex with minors (Articles 237-8 and 358). The age of consent for sexual activity is 14 years, with no restrictions on gender or sexual orientation. An amendment to Article 237 in 2015 stipulates a maximum of five years imprisonment for indecent assault on others (male or female), whereas it previously only referred to the sexual assault of women ('Zhonghua renmin gongheguo xingfa xiuzhengan (9)' 2015: Item 13). But the Law criminalizes some acts as harmful that may limit freedom of sexual expression, such as the third-party organization of prostitution and orgies, and the manufacture and distribution of pornography (Sections 8-9 and Article 301). 
Elaine Jeffreys (2018) 'Public Policy and LGBT People and Activism in Mainland China', in W. Lam (ed.) Routledge Handbook of the Chinese Communist Party, Abingdon: Routledge, pp. 283-96.

ISBN: 9781138684430. (Author Copy: 22 January 2017)

Prior to 1997, homosexual men were sometimes detained by police for engaging in acts of 'hooliganism' (liumangzui) or 'other hooligan activities' (qita liumang huodong) based on a 1984 ruling by the Supreme People's Court (Zuigaorenminfayuan, zuigaorenminjianchayuan 1984). The ruling defined 'hooliganism' in terms of fighting, looting, sexually harassing women, and causing public disturbance. 'Other hooligan activities' referred to group sex, the dissemination of pornography, the not-for-profit luring or sheltering of women in prostitution, the seducing of male adolescents and foreigners, the sodomy of children, the forced sodomy of juveniles, and violent or non-consensual anal sex involving adults. While referring in theory to non-consensual sex acts, the police often used the category of 'hooliganism' as an umbrella term for acts they deemed to be causing public disturbance or offence until it was deleted from the Criminal Law in 1997. To the extent that police targeted homosexuals, they tended to police public spaces that men who have sex with men were known to frequent to find sexual partners and engage in sex acts, such as public toilet blocks and parks (Li 2009: 86-7). Lesbianism remained a more hidden, as in non-public practice.

The establishment of support organizations for homosexuals was also restricted by Party-state authorities. In late 1992, Wan Yanhai (2001: 60), now a renowned LGBT activist, organized a salon called 'Men's World', a health promotion group for same-sex attracted men, which held a Valentine's Day celebration in 1993. While encouraging similar gatherings in other cities, the salon was promptly closed down. The Ministry of Public Security issued a document about this titled Notice on the Closure of the 'Men's World' Homosexual Culture Salon (Gonganbu 1993). The Notice stated that the salon had been closed down at the request of the Ministry of Health because of public complaints. It rejected Wan Yanhai's contention that homosexuality was normal, stating instead that homosexuality was a perverse form of human behaviour that violated public morality, corrupted social values, destroyed family harmony, encouraged criminality, endangered public security and contributed to the spread of AIDS. While noting that such gatherings did not comprise a form of hooliganism, the Notice concluded that similar homosexual gatherings could be investigated and closed down as 'unlawful assemblies' (Ibid.).

In addition to negative policing approaches, homosexuality was defined medically in terms of sexual dysfunction and mental disorder until 2001. Scholars contend that the pathologization 
Elaine Jeffreys (2018) 'Public Policy and LGBT People and Activism in Mainland China', in W. Lam (ed.) Routledge Handbook of the Chinese Communist Party, Abingdon: Routledge, pp. 283-96.

ISBN: 9781138684430. (Author Copy: 22 January 2017)

of homosexuality in terms of deviancy, perversion and psychosexual disorder entered China from western sexology in the early- to mid-twentieth century. While medical understandings of homosexuality changed dramatically in western societies from the late 1970s onwards, they remained largely unquestioned in the more closed society of China until the 1990s (Chou 2000: 110-13).

Homosexuality was defined as a psychosexual disorder in a text published by the Chinese Society of Psychiatry in 1981, which was used as a clinical guide for the diagnosis of mental disorders. That text was retrospectively titled the first Chinese Classification of Mental Disorders (CCMD-1) in 1989, when it was replaced by the official 'second' Chinese Classification of Mental Disorders (CCMD-2). The description of homosexuality in terms of mental disorder was not removed from the Chinese Classification of Mental Disorders until it was revised again in 2001 (CCMD-3) (Chinese Society of Psychiatry 2001). It is worth noting that the World Health Organization (1992) only removed homosexuality from its classification of mental and behaviour disorders at the Forty-Third World Health Assembly in May 1990, with a new International Classification of Diseases coming into effect in member states in 1994. Hence, the PRC's scientific redefinition of homosexuality followed from the eventual adoption of international standards.

Despite a history of policing and medical controls, public expressions of LGBT identities in the PRC were and are constrained mainly by social expectations. Wah-Shan Chou (2000: 27) argues that, strictly speaking, there were no 'homosexuals' or 'bisexuals' or even 'heterosexuals' in China until recently. Although some people engaged in same-sex sexual practices, Chinese society was not divided according to a homo-hetero binary as in modern western societies, and same-sex eroticism was not associated with a particular form of personality or identity. Instead, Chinese society was organized around class hierarchies and different levels of responsibilities to family and kinship networks. This meant that same-sex eroticism was tolerated to the extent that it did not interfere with the familial obligation to marry and have male children to continue the family line, and hence was publicly 'invisible'.

Some same-sex attracted people claim that the major problem faced by people in China who wish to live openly as LGBT is 'not state oppression, religious fundamentalism, or job discrimination', but rather their relatives and peers (Chou 2001: 34). People of marrying age 
Elaine Jeffreys (2018) 'Public Policy and LGBT People and Activism in Mainland China', in W. Lam (ed.) Routledge Handbook of the Chinese Communist Party, Abingdon: Routledge, pp. 283-96.

ISBN: 9781138684430. (Author Copy: 22 January 2017)

are pressured to get married by family, friends and work colleagues, with data from the PRC's 2010 Population Census demonstrating that less than 2 per cent of men and women aged forty years and over had never married (Jeffreys and Yu 2015: 15). An estimated 2 per cent of LGBT people avoid heterosexual marriage by coming out to their parents (Fullerton 2015). Some avoid or delay social pressures to marry by 'going out' (chuzou), literally moving away from their place of birth and family home, and practising a classical Chinese aesthetic of 'don't ask, don't tell' with their families and colleagues (Jeffreys and Yu 2015: 89). However, many gays and lesbians view entering a heterosexual marriage as 'the right thing to do' despite their sexual orientation, and others enter marriages of convenience in order to pass as 'straight' to family and work colleagues (see below).

The PRC's now defunct one-child-per-couple policy has variously eased and enhanced pressure on young LGBT people to enter a heterosexual marriage. It has ensured that some parents and grandparents are prepared to accept the non-traditional sexual and lifestyle choices of their only child/grandchild in order to retain a relationship with them (Ibid.: 94). But other parents place even more pressure on an only child to marry, reproduce and otherwise lead a successful, 'normal' life. This situation has trapped an estimated 16 million homosexual men and heterosexual women in marriages; comparative estimates are not available for lesbians (Ibid.: 39). In the words of one self-identified Chinese gay man who says he would consider marrying a woman to please his parents: 'I am not ashamed of being gay at all. I only care about my family' (Lau 2010, see Wuhan - Robin's story).

Although the PRC has legislation that includes general anti-discrimination provisions, the body of Chinese law contains no specific reference to sexual orientation and gender identity. Article 33 of the Constitution of the PRC (1982) stipulates that all citizens are equal before the law and Article 48 states that women enjoy equal rights with men in all spheres of life, and are entitled to equal pay for equal work and equal access to opportunities for work. However, the focus is on gender discrimination against women understood as a disadvantaged group by virtue of biological sex. The Labour Law of the PRC (1995) similarly prescribes that there should be no employment and workplace discrimination based on the factors of ethnicity, gender (read biological sex) and religious affiliation, and makes no reference to sexual orientation or gender identities. 
Elaine Jeffreys (2018) 'Public Policy and LGBT People and Activism in Mainland China', in W. Lam (ed.) Routledge Handbook of the Chinese Communist Party, Abingdon: Routledge, pp. 283-96.

ISBN: 9781138684430. (Author Copy: 22 January 2017)

Yet reports exist of bullying and discrimination against LGBT individuals in education and work situations, and of people choosing not to reveal their sexual orientation or gender identity in these contexts (UNDP, USAID 2014: 9). Such discrimination is largely hidden and unaddressed. This is because public discourse on LGBT issues has been stymied by the historical invisibility of LGBT people, and by state controls over the media and civil sector.

State controls over the PRC's media and civil sector mean that there are limited venues for positive self-presentations of LGBT issues or for organized advocacy designed to report and end discrimination against LGBT people. Mainstream media coverage of LGBT issues is often inadequate or based on stigmatizing stereotypes that associate homosexuality with deviancy and disease (UNDP, USAID 2014: 12). Regulations issued by the State Administration of Press, Publication, Radio, Film and Television in 2006 banned the inclusion of content relating to pornography, licentiousness, rape, commercial sex, sexual perversion and sex organs ('Guojia guangbo dianying dianshi zongju ling' 2006: Article 14, Item 3). A 2008 Notice on 'film and television censorship standards' added homosexual sex and masturbation to the list of banned sexual content (Zhonghua renmin gongheguo guojia xinwen chuban guangdian zongju 2008: Article 3). Although the 2008 notice was replaced by new regulations in 2010 that make no explicit mention of homosexuality, the potential for government censorship encourages self-censorship on the part of individuals and organizations both to avoid regulatory repercussions and maintain commercial viability. This means that the majority of LGBT-themed media products and publications are independently produced and not widely circulated outside of LGBT circles (Jeffreys and Yu 2015: 82-4; UNDP, USAID 2014: 44-5).

The potential for government censorship encourages the circulation of specific types of LGBT-themed information. LGBT-related publications are usually associated with AIDS education; the few available studies of sexual and gender minorities are often published in Hong Kong or Taiwan because they are declined by publishers on the mainland (UNDP, USAID 2014: 44-5). Although the number of LGBT community websites and social networks is increasing, education- and advocacy-orientated sites practice self-censorship to avoid the risk of being shut down. Other sites are commercialized rather than advocacyorientated in order to avoid censors and attract traffic and money from advertising (Jeffreys and Yu 2015: 82-3). 
Elaine Jeffreys (2018) 'Public Policy and LGBT People and Activism in Mainland China', in W. Lam (ed.) Routledge Handbook of the Chinese Communist Party, Abingdon: Routledge, pp. 283-96.

ISBN: 9781138684430. (Author Copy: 22 January 2017)

Government regulations also indirectly restrict the number and types of LGBT organizations by requiring civil sector organizations to be legally registered and comply with national policy goals, directing resources towards issues such as AIDS and excluding others. Chinese NGOs in most social issue areas have emerged and flourished 'only insofar as their activities complement government interests' (Hildebrandt 2012: 853). In the case of LGBT organizations, the lion's share of international and domestic funding has gone to groups working on HIV prevention, with such groups being 'loud about AIDS but quiet about other issues in order to enjoy the most political space' (Ibid.). Fewer organizations focus on the lived experiences of LGBT people and encourage capacity building for new groups across the country, including in poorer regions (UNDP, USAID 2014: 19).

Bisexual and transgender organizing is chiefly conducted through online chat groups rather than offline, and groups working with transgender communities typically work with male-tofemale transgender sex workers on HIV prevention (Asia Catalyst 2015). Research and organizing on intersexuality - people who have physical, hormonal or genetic features that are neither wholly female nor wholly male or a combination of female and male or neither female nor male - is even less available than it is for other LGBT groups (UNDP, USAID 2014: 28). Small LGBT organizations are often unregistered and staffed by volunteers, which enables them to pursue agendas other than those endorsed by government but also potentially weakens their sustainability (Ibid.: 50). International NGOs fear that the enforcement of the Law on the Management of Overseas NGOs' Activities in Mainland China, effective 1 January 2017, will enhance existing controls and constraints.

Last, but not least, LGBT communities and organizations are recent phenomena in China; as such, they do not comprise a unified or coherent social movement. Conflicts and tensions between groups are common 'due to lack of communication, mutual discrimination and the unbalanced distribution of resources' (UNDP, USAID 2014: 47; see also Hildebrandt 2012: 857). But domestic activism by and on behalf of LGBT people is taking place, as the next section explains.

\section{Anti-discrimination and same-sex marriage}


Elaine Jeffreys (2018) 'Public Policy and LGBT People and Activism in Mainland China', in W. Lam (ed.) Routledge Handbook of the Chinese Communist Party, Abingdon: Routledge, pp. 283-96.

ISBN: 9781138684430. (Author Copy: 22 January 2017)

In recent years, LGBT activists have staged a series of coordinated events designed to raise public and government awareness of LGBT issues in the PRC via media publicity of landmark legal cases and innovative public advocacy. Some of these activities are detailed below. They include legal suits filed against diverse government departments for failing to restrict homophobic representations and attitudes, preventing positive self-presentations of LGBT people and denying the civil rights of same-sex couples.

In August 2015, a female university student named Chen Qiyan filed a case of administrative inaction against the Guangdong Education Department with the Beijing Second Intermediate People's Court, after a letter of complaint about a homophobic textbook that she had written to the department in March 2015 was ignored. Regulations stipulate that government departments should reply to complaints within 15 days (Xu 2015). The Los Angeles Times endorsed the courts' acceptance of the case as an 'important step' forward for gay rights in China, while noting that a university counsellor had telephoned Chen's parents about the case and informed them of her sexuality without her consent (Kaiman 2015). Chen withdrew the case later that year, telling reporters that her goal of drawing public attention to the negative impact of homophobia had been achieved (Xu 2016).

This case comprised a formal extension of earlier activism associated with International Day against Homophobia and Transphobia. Founded on 17 May 2005 to commemorate the removal of homosexuality from the WHO's International Classification of Diseases, this annual event aims to raise awareness of LGBT rights' violations worldwide (http://dayagainsthomophobia.org/). China's largest gay website, Danlan.org, launched a campaign called Expose the Homophobic Teaching Materials Around You in 2012 ('Danlan 5.17 xilie huodong' 2013). Danlan's popularity is demonstrated by its location-based flirting app, Blued, which had 27 million members in 2017 (www.blued.com/en/). Thirteen textbooks were exposed at a May 2013 press conference for including claims that homosexuality undermines social order and spreads AIDS (Yang 2013: 16-17).

In December 2015, the Beijing Number One Intermediate People's Court ruled on a landmark case filed by independent filmmaker, Fan Popo, asking the State Administration of Press, Publication, Radio, Film and Television (SAPPRFT) why trailers for his LGBT-themed documentary, Mama Rainbow, had been removed from video-streaming websites (Zhang 
Elaine Jeffreys (2018) 'Public Policy and LGBT People and Activism in Mainland China', in W. Lam (ed.) Routledge Handbook of the Chinese Communist Party, Abingdon: Routledge, pp. 283-96.

ISBN: 9781138684430. (Author Copy: 22 January 2017)

2015). Mama Rainbow documents the love of six Chinese mothers for their homosexual children (Fan 2012). The court determined that SAPPRFT had not issued any notice asking for the trailer to be removed. Fan hailed this ruling as a victory against government censorship and associated corporate self-censorship, because it implied that his documentary was not banned and therefore could be shown on the Internet (Zhang 2015).

In another history-making case, a labour arbitration panel in Guizhou Province ruled against China's first case of transgender job discrimination in May 2016 (Piao 2016). A man named 'Mr C' filed a suit against his employer, a health centre, for wrongful dismissal at the end of a brief probation period. Mr C argued that he was born a woman and had been denied ongoing employment for wearing male clothing to work. The court accepted instead the employers' claim that Mr C's employment had been terminated for documented reasons of incompetency.

In yet another landmark case, a man named Sun Wenlin filed a case against the Furong Civil Affairs Bureau in Changsha City for refusing to register a marriage between him and his male partner. The court's acceptance of the case in January 2016 attracted international publicity in the wake of the June 2015 US Supreme Court ruling, which ruled that individual states in the USA could not ban same-sex marriage without abrogating constitutional guarantees of due process and equal protection under the law. President Obama described the ruling as a milestone in American justice and the White House was lit in rainbow colours to mark the administration's support of the court's decision. The ruling generated widespread interest on Chinese social media, resulting in companies such as Taobao, an online shopping platform, placing the rainbow flag on their homepages (Hewitt 2015).

In April 2016, the Changsha court rejected Sun's claim that the PRC's Marriage Law is nongender specific and affirmed that marriage can only take place between a man and a woman according to extant law. However, the court's acceptance of the case is viewed as a milestone in terms of LGBT affirmative action on civil rights. It highlights the potential to alter regulations related to the legal registration of a marriage in China, which are administrative rather than celebratory or religious in nature (Jeffreys and Wang 2013: 349-54).

Previously, same-sex marriage had been debated in China chiefly in relation to the negative effects of family and social pressure for LGBT people to enter heterosexual relationships, 
Elaine Jeffreys (2018) 'Public Policy and LGBT People and Activism in Mainland China', in W. Lam (ed.) Routledge Handbook of the Chinese Communist Party, Abingdon: Routledge, pp. 283-96.

ISBN: 9781138684430. (Author Copy: 22 January 2017)

rather than as a regulatory reform issue. Social pressure on men to marry for the purposes of continuing the family line has reportedly resulted in 16 million Chinese women being married to homosexual or bisexual men, with most women being unaware of their spouses' sexual orientation, at least initially (Jeffreys and Yu 2015: 39). As married women in the PRC typically use intrauterine devices for contraception, condom use is not normally practiced in the context of marital sex with an associated potential for the spread of sexually transmissible infection. Studies of the sexual behaviours of Chinese men who have sex with men, including male-male sex workers, indicate that approximately 30 per cent of such men have concurrent female partners, and nearly 77 per cent have unprotected sex with primary female partners (Wang et al. 2015: 126-7).

Some LGBT people have responded to heteronormative social demands by entering a 'cooperative marriage', that is, a marriage between two homosexuals of the opposite gender who present themselves to family and work circles as a heterosexual couple, while maintaining separate gay and lesbian sex lives. There is no detailed information available about the practical and psychological complications of performing heterosexual love in front of families and colleagues for prolonged periods, or the legal complications regarding finances and child custody should the 'marriage' fail (Kam 2013: 101). But there are now websites that help individuals to find cooperative-marriage partners, and provide pre- and post-marriage advice and support. ChinaGayLes.com claimed to have had more than 400,000 registered users and assisted nearly 49,000 such marriages by 2017 (www.chinagayles.com/).

Anecdotal evidence suggests that LGBT people experience cooperative marriages in mixed ways. In a media interview, one participant described his wife as a 'sister' and spoke of his love for their son, who his wife had conceived by using a plastic syringe to insert his sperm (Jeffreys and Yu 2015: 40). Conversely, cooperative marriage is described as a 'nightmare' by a lesbian who experienced difficulties dealing with her partner as a 'wife' and dealing with his 'husband', and as 'torture' by a gay man who described his 'wife' as unreasonable and was pressured to have a child by both his parents and his 'wife's' parents (Ibid.: 92). Although cooperative marriages underscore the strong social pressure to marry, they also point to the growth of LGBT communities, a development which may limit the number of such marriages in the future. 
Elaine Jeffreys (2018) 'Public Policy and LGBT People and Activism in Mainland China', in W. Lam (ed.) Routledge Handbook of the Chinese Communist Party, Abingdon: Routledge, pp. 283-96.

ISBN: 9781138684430. (Author Copy: 22 January 2017)

Activists Li Yinhe and Lin Xianzhi have advocated instead for legal protections for same-sex couples during the annual meetings of the National People's Congress (NPC) and the Chinese People's Political Consultative Conference (CPPCC), the PRC's legislature and a political advisory body respectively. Li Yinhe is a famous sociologist and sexual rights' activist; her Sina.com blog alone had received nearly 100 million visitors by 2017 ('Li Yinhe de boke' 2017). Li unsuccessfully lobbied delegates at the CPPCC to consider a proposal on legalizing same-sex marriage on at least seven occasions between 2003 and 2016. Her proposal states that legalizing same-sex marriage will reduce the spread of HIV, revive China's traditional cultural acceptance of same-sex eroticism, and build the PRC's international reputation as a promoter rather than violator of human rights (Jeffreys and Yu 2015: 165). While failing to obtain formal political traction, Li's lobbying has attracted publicity and debate, being praised for demonstrating China's social progress and criticized for encouraging 'abnormal' behaviours (Ibid.: 165).

Li Yinhe also attracted publicity in 2014-2015 when she announced on China's Twitter-like Weibo that her longstanding partner is a transman (a person categorized as female at birth whose gender identity is that of a man). The People's Daily - the official mouthpiece of the Communist Party -responded to her revelations with support on its weibo. The Editor stated that homosexuality and transsexuality are increasingly accepted in mainstream Chinese society, and that respecting one's personal views also means respecting 'the choices of the $\mathrm{Li}$ Yinhe's among us' (Renmingwang weiping 2014).

Lin Xianzhi, a retired government official, and member of PFLAG China, petitioned representatives at the NPC in 2015 to give young gay couples legal protections, while capitalizing on his son's temporary fame as a finalist in the 2015 Valentine's Day 'Rainbow Love' contest hosted by Taobao (Doland 2015). Founded in 2008, PFLAG China has subgroups across the PRC (pflag.org.cn) and is an independent version of PFLAG (an acronym for Parents and Friends of Lesbians and Gays, an organization founded in the USA in the 1970s that now supports families and friends of LGBT and queer people). Taobao hosted the contest, which featured as a rotating advertisement on the Taobao homepage, through partnerships with the global marketing company China Luxury Advisors and Danlan, PFLAG China and the Beijing LGBT Center. The competition offered ten same-sex Chinese couples an all-expenses paid trip to California to get married during a group wedding there, 
Elaine Jeffreys (2018) 'Public Policy and LGBT People and Activism in Mainland China', in W. Lam (ed.) Routledge Handbook of the Chinese Communist Party, Abingdon: Routledge, pp. 283-96.

ISBN: 9781138684430. (Author Copy: 22 January 2017)

with funding from a Chinese bedding company. Taobao users voted on the finalists based on short videos of the couples telling their stories about how they met and fell in love, and why they want to get married. Over 400 couples competed, one million people viewed the event page, and more than 75,000 people voted.

Lin's actions highlight an interesting convergence of activist, parental and commercial concerns to promote LGBT rights in the formal political context of the NPC. The couples who entered the Taobao-hosted competition were recruited through LGBT networks, and had the support of families, friends and work colleagues to compete, or else were unconcerned about the social consequences of having their images and love stories presented on social and broadcast media. Lin's son entered the competition as an 'out' gay with a father who openly supports his son's right to live without discrimination as a member of PFLAG China. Lin petitioned the NPC as a parent speaking for the parents of all children who worry about the future security of their child and their child's partner, and especially when their child's sexual orientation or gender identity affords them no legal protections in relation to medical care, property purchase and inheritance (Zhang 2015). Here, Lin used conservative (Confucian) conceptions of family obligations to argue for improved legal protections for people in nonheterosexual relationships.

Taobao's use of advertising featuring same-sex couples demonstrates commercial interest in the Chinese 'pink market' potential. Taobao representatives did not emphasize this point, saying instead that the 'Rainbow Love' contest aimed to increase 'respect and understanding for homosexuality, and support the realization of dreams' (Doland 2015). The company reiterated this claim by featuring the rainbow flag on its homepage following the US Supreme Court ruling. However, given the limited media and political spaces for positive selfportrayals of LGBT people in China, business interest in the pink market has the potential to open the space for public discussion of LGBT issues.

As in other parts of the world, Chinese LGBT struggles for sexual citizenship may soon become entangled with commercial interests and consumer activities. This could expand the availability of LGBT-themed venues, products and events, especially for members of younger generations. It could also generate alternative funding for LGBT events and activism 
Elaine Jeffreys (2018) 'Public Policy and LGBT People and Activism in Mainland China', in W. Lam (ed.) Routledge Handbook of the Chinese Communist Party, Abingdon: Routledge, pp. 283-96.

ISBN: 9781138684430. (Author Copy: 22 January 2017)

via niche and cause-related marketing, and through the gradual expansion in China of corporate- and celebrity-endorsed philanthropy.

\section{Conclusion}

The preceding discussion suggests that some LGBT people in the PRC are moving away from a 'don't ask, don't tell mentality', but that the development of a more enabling environment for LGBT individuals and groups requires recognition and support from the government and private sector. In the words of one gay man: 'The current situation is more and more people are becoming open-minded. But the government does not say anything good or bad about it. They just keep silent' (Lau 2010, see Wuhan - Robin's story).

Somewhat paradoxically, in a country where struggles for sexual rights are usually couched as demands for diminished Party-state intervention in the 'private' domain of sexuality, this is in part a call for enhanced government intervention to realize legal and social reform.

Homosexuality is neither criminalized nor a focus of religious proscriptions in contemporary China. However, government inaction on LGBT issues to date has been ensured by economic and political priorities, and conservative family and sexual mores. To the extent that government in general views changes in community public perception as a signal for regulatory change, this approach may alter in the near future. Such a shift is also indicated by the PRC government's acceptance of UN recommendations that it establish antidiscrimination legislation to ensure that LGBT people enjoy equal treatment (United Nations General Assembly 2013).

What kind of support is required? There is a need to introduce and enforce antidiscriminatory and affirmative legislation. This would include: (1) banning stigmatizing and discriminatory practices in the media, the workplace and in schools; (2) promoting positive representations of LGBT people; (3) making same-sex couples equal to married heterosexual couples by protecting partner rights, such as joint property, hospital visits, adoption and inheritance; and (4) extending healthcare services to include the needs of homosexual, transgender and intersex people. That means training Party officials, government employees, police officers, lawyers, media professionals, healthcare providers and educators, and 
Elaine Jeffreys (2018) 'Public Policy and LGBT People and Activism in Mainland China', in W. Lam (ed.) Routledge Handbook of the Chinese Communist Party, Abingdon: Routledge, pp. 283-96.

ISBN: 9781138684430. (Author Copy: 22 January 2017)

creating a relevant government department to oversee the introduction and implementation of such policies (UNDP, USAID 2014: 13-16).

There is also a need for the reform of regulations relating to media censorship and the registration of LGBT community and HIV prevention groups. These restrictions directly or indirectly limit the development of LGBT culture and expression, and subsequently public awareness and acceptance of LGBT people. They also limit the potential for commercial and philanthropic funding to support research that can inform community actions and policymaking, and to establish support groups for LGBT youth, transgenders, bisexuals and people living in undeveloped parts of China.

In short, overcoming the lousy state of LGBT rights in China will not happen overnight for three reasons. First, it requires the political will and funding necessary for a significant restructuring of sectors of government. Second, it demands the development of a coordinated LGBT movement with influential organizations and spokespersons, and capacity-building professionals that can both support LGBT people and generate community support for LGBT issues. Finally, it means developing a domestic consumer and philanthropic culture that promotes sexual diversity by providing private services and sources of funding for LGBT people, organizations and events.

\section{References}

Asia Catalyst (2015) 'My life is Too Dark To See the Light': A Survey of the Living Conditions of Transgender Female Sex Workers in Beijing and Shanghai, New York: Asia Catalyst.

Australian Human Rights Commission (2013) 'New protection', 1 August, available: https://www.humanrights.gov.au/our-work/sexual-orientation-sex-genderidentity/projects/new-protection (accessed 22 January 2017).

Bai, T. (2016) '190 Chinese LGBT groups condemn Orlando club shooting', Global Times, 14 June, available: http://www.globaltimes.cn/content/988160.shtml (accessed 22 January 2017). 
Elaine Jeffreys (2018) 'Public Policy and LGBT People and Activism in Mainland China', in W. Lam (ed.) Routledge Handbook of the Chinese Communist Party, Abingdon: Routledge, pp. 283-96.

ISBN: 9781138684430. (Author Copy: 22 January 2017)

Bedell, G. (2007) 'Coming out of the dark ages', The Guardian, 24 June, available: http://www.theguardian.com/society/2007/jun/24/communities.gayrights (accessed 22 January 2017).

'Changsha - yi nanzi wei jing xuke zuzhi fandui tongxinglian qishi youxing bei juliu' [Changsha - a man is detained by police for holding a parade to protest discrimination against homosexuality without permission] (2013) Xinhua, 21 May. Available at: http://news.china.com/domestic/945/20130521/17844850.html (accessed 22 January 2017).

Chinese Society of Psychiatry (2001) Zhongguo jingshenzhang'ai fenlei yu zhenduan biaozhun disanban [Chinese Classification for Mental Disorders Version 3 (CCMD-3)], Jinan: Shandong Kexuejishu Chubanshe.

Chou, W.-S. (2000) Tongzhi: Politics of Same-sex Eroticism in Chinese Societies, Binghamton: The Haworth Press.

Chou, W.-S. (2001) 'Homosexuality and the cultural politics of tongzhi in Chinese societies', Journal of Homosexuality, 40, 3-4: 27-46.

Constitution of the People's Republic of China (1982) Adopted 4 December 1982. Available at: http://en.people.cn/constitution/constitution.html (accessed 22 January 2017).

Criminal Law of the People's Republic of China (1997) Adopted by the Second Session of the Fifth National People's Congress on 1 July 1979 and amended by the Fifth Session of the Eighth National People's Congress on 14 March 1997. Available at:

http://www.fmprc.gov.cn/ce/cgvienna/eng/dbtyw/jdwt/crimelaw/t209043.htm (accessed 22 January 2017).

'Danlan 5.17 xilie huodong: jielu ni shenbian de kongtong jiaocai' [Danlan 17 May activities: exposes the homophobic teaching materials around you] (2013) Danlan.org, 25 May. Available at: http://www.danlan.org/disparticle_43578.htm (accessed 22 January 2017). 
Elaine Jeffreys (2018) 'Public Policy and LGBT People and Activism in Mainland China', in W. Lam (ed.) Routledge Handbook of the Chinese Communist Party, Abingdon: Routledge, pp. 283-96.

ISBN: 9781138684430. (Author Copy: 22 January 2017)

Davies, G. and Davies, M.E. (2010) 'Jin Xing: China’s transexual star of dance', in L. Edwards and E. Jeffreys (eds) Celebrity in China, Hong Kong: Hong Kong University Press, pp. 169-91.

Doland, A. (2015) 'For Valentine’s Day, Alibaba helps gay Chinese couples get married in the U.S.', AdvertisingAge, 12 February. Available at: http://adage.com/article/globalnews/alibaba-helps-chinese-gay-couples-married-u-s/297108/ (accessed 22 January 2017).

Engebretsen, E., Schroeder, W. and Bao, H. (eds) (2015) Queer/Tongzhi China: New Perspectives on Research, Activism and Media Cultures, Nordic Institute of Asian Studies Gendering Asia.

Fan, Popo (2012) Mama Rainbow - trailer, YouTube, 12 May. Available at: https://www.youtube.com/watch?v=hFTVOnaixKM (accessed 22 January 2017).

Fan, Y. (2016) 'Meet the lawyers fighting for LGBT rights', Sixth Tone, 8 April. Available at: http://www.sixthtone.com/news/meet-lawyers-fighting-lgbt-rights (accessed 26 August 2016).

Fullerton, J. (2015) 'China's attitude toward homosexuality is beginning to shift, with parents leading the way', Vice News, 10 April. Available at: https://news.vice.com/article/chinasattitude-toward-homosexuality-is-beginning-to-shift-with-parents-leading-the-way (accessed 22 January 2017).

Gonganbu (1993) 'Guanyu qudi tongxinglian wenhua shalong 'nanren de shijie’ de qingkuang tongbao' [Notice on the closure of the "Men's World" homosexual culture salon], Gong tong zi [1993] 62 hao. Available at: http://www.chinaacc.com/new/63\%2F71\%2F2006\%2F3\%2Fxu67353159133600230290.htm (accessed 22 January 2017).

Guojia guangbo dianying dianshi zongju ling: di 52 hao' [Order No. 52 of the State Administration of Radio, Film and Television] (2006) Dianying juben (genggai) bei'an, dianying pian guanli guiding [Regulations for the administration of the records of screenplay 
Elaine Jeffreys (2018) 'Public Policy and LGBT People and Activism in Mainland China', in W. Lam (ed.) Routledge Handbook of the Chinese Communist Party, Abingdon: Routledge, pp. 283-96.

ISBN: 9781138684430. (Author Copy: 22 January 2017)

(outline) and films], issued 3 April 2006, effective 22 June 2006. Available at:

http://www.sarft.gov.cn/art/2006/6/22/art_1583_26305.html (accessed 22 January 2017).

Hamer, D. (2014) 'Hiding in plain sight: the Beijing queer film festival', Filmmaker, 7 January. Available at: http://filmmakermagazine.com/88879-hiding-in-plain-sight-thebeijing-queer-film-festival/\#.Vl-RsM7otjo (accessed 11 August 2016).

Hewitt, D. (2015) 'US Supreme Court ruling on gay marriage prompts "unprecedented" debate in China, gives hope to gay activists', IBT, 29 June. Available at: http://www.ibtimes.com/us-supreme-court-ruling-gay-marriage-prompts-unprecedenteddebate-china-gives-hope-1987592 (accessed 22 January 2017).

Hildebrandt, T. (2012) 'Development and division: the effect of transnational linkages and local politics on LGBT activism in China', Journal of Contemporary China, 21, 77: 845-62.

Hong, B. (2015) 'China has one amazing transsexual celeb - but lousy LGBT rights', The Daily Beast, 28 March. Available at:

http://www.thedailybeast.com/articles/2015/03/28/china-has-one-amazing-transsexual-celebbut-lousy-lgbt-rights.html (accessed 11 August 2016).

Jeffreys, E. (2012) Prostitution Scandals in China: Policing, Media and Society, Abingdon: Routledge.

Jeffreys, E. and Wang, P. (2013) 'The rise of Chinese-foreign marriage in mainland China (1979-2010)', China Information, 27, 3: 347-69.

Jeffreys, E. and Yu, H-Q. (2015) Sex in China, Cambridge: Polity.

Jin Xing tuokou хіи [The Jin Xing Show] (2015) Sohu. Available at: http://tv.sohu.com/s2014/jxtkx/ (accessed 22 January 2017). 
Elaine Jeffreys (2018) 'Public Policy and LGBT People and Activism in Mainland China', in W. Lam (ed.) Routledge Handbook of the Chinese Communist Party, Abingdon: Routledge, pp. 283-96.

ISBN: 9781138684430. (Author Copy: 22 January 2017)

Kaiman, J. (2015) “"An important step” for gay rights in China, Los Angeles Times, 24

November. Available at: http://www.latimes.com/world/asia/la-fg-gay-rights-china-

20151124-story.html (accessed 22 January 2017).

Kam, L.Y.L. (2013) Shanghai Lalas: Female Tongzhi Communities and Politics in Urban China, Hong Kong: Hong Kong University Press.

Kong, T.S.K. (2010) Chinese Male Homosexualities: Memba, Tongzhi and Golden Boy, Abingdon: Routledge.

Labour Law of the People's Republic of China (1995) 1 January. Available at: http://www.china.org.cn/living_in_china/abc/2009-07/15/content_18140508.htm (accessed 22 January 2017).

Lau, S. (2010) 'Homosexuality in China', US-China Today, 10 March. Available at: http://www.uschina.usc.edu/w_usct/showarticle.aspx?articleID=14740\&AspxAutoDetectCoo kieSupport=1 (accessed 22 January 2017).

'Li Yinhe de boke' [Li Yinhe's blog] (2017) Sina.com, available: http://blog.sina.com.cn/liyinhe (accessed 22 January 2017).

Li, Y. (2009 [2006]) 'Regulating male same-sex relationships in the People's Republic of China', in E. Jeffreys (ed.) Sex and Sexuality in China, Abingdon: Routledge, pp. 82-101.

Liebman, B. (2014) 'Legal reform: China’s law-stability paradox', Daedalus, 143, 2: 96-109.

Piao, V. (2016) 'Chinese panel rules against plaintiff in transgender job discrimination case', New York Times, 10 May. Available at: http://www.nytimes.com/2016/05/11/world/asia/china-transgender-jobdiscrimination.html?_r=0 (accessed 22 January 2017).

'Pride of tolerance' (2009) China Daily, 10 June, p. 8. 
Elaine Jeffreys (2018) 'Public Policy and LGBT People and Activism in Mainland China', in W. Lam (ed.) Routledge Handbook of the Chinese Communist Party, Abingdon: Routledge, pp. 283-96.

ISBN: 9781138684430. (Author Copy: 22 January 2017)

Renmingwang weiping [People's commentary] (2014) People.cn, 19 December. Available at: http://weibo.com/2286908003/BBAf1EJ7W?type=comment\#_rnd1464314720702 (accessed 27 May 2016).

Roxburgh, H. (2016) 'Risqué business: first Mr Gay China shows new, more public face of LGBT', The Guardian, 6 August.

UNDP, USAID (2014) Being LGBT in Asia: China Country Report, Bangkok.

United Nations General Assembly (2013) Human Rights Council Twenty-fifth Session Agenda Item 6: Universal Periodic Review, Report of the Working Group on the Universal Periodic Review, China (including Hong Kong, China and Macao, China), 4 December.

Wan, Y-H. (2001) 'Becoming a gay activist in contemporary China', Journal of Homosexuality, 40, 3: 47-64.

Wang, S., Song, D., Huang, W., He., H., Wang, M., Manning, D., Zaller, N., Zhang, H. and Operario, D. (2015) 'Heterosexual partnerships and the need for HIV prevention and testing for men who have sex with men and women in China: a qualitative study', AIDS Education and Prevention, 27, 2: 126-38.

World Health Organization (1992) The ICD-10 Classification of Mental and Behavioural Disorders - Clinical Descriptions and Diagnostic Guidelines, Geneva: World Health Organization.

$\mathrm{Xu}$, Jing (2015) 'Yi wumie tongxinglian xuesheng jubao jiaocai' [Students reported textbooks for slandering homosexuals], Guangzhou Ribao, 20 March, A16.

Xu, Xiaoyang (2016) 'Yin jiaocai "kongtong” qisu jiaoyubu zhongda nüsheng chesu: jiben suqiu yijing dadao [The female Chinese university student who filed a case against the Ministry of Education on "homophobic" textbooks withdrew her case because the appeal had already achieved her objectives], Pengpai Xinwen. Available at:

http://www.thepaper.cn/newsDetail_forward_1421090 (accessed 22 January 2017). 
Elaine Jeffreys (2018) 'Public Policy and LGBT People and Activism in Mainland China', in W. Lam (ed.) Routledge Handbook of the Chinese Communist Party, Abingdon: Routledge, pp. 283-96.

ISBN: 9781138684430. (Author Copy: 22 January 2017)

Yang, J. (2013) 'Activists battle to eliminate discrimination taught in schools', Global Times, 24 May, pp. 16-17.

Yau, C. (ed.) (2010) As Normal as Possible: Negotiating Sexuality and Gender in Mainland China and Hong Kong, Hong Kong: Hong Kong University Press.

Zhang, Weibin (2015) 'Fan Popo shengsu, fayuan de panjueshu youdian aimei' [The court ruling in favour of Fan Popo is ambiguous], 163.com, 6 December. Available at: http://news.163.com/15/1226/08/BBOH2GA100014AEE.html (accessed 22 January 2017).

Zhang, Y. (2015) 'Gay marriage advocates ask legislators to present their proposals at the two sessions', Global Times, 16 March. Available at:

http://www.globaltimes.cn/content/912260.shtml (accessed 22 January 2017).

Zhonghua renmin gongheguo guojia xinwen chuban guangdian zongju (2008) 'Guangdian zongju guanyu chongshen dianying shencha biaozhun de tongzhi' [The State Administration of Radio, Film and Television Notice on Reiterating Film Censorship Standards], 7 March. Available at: http://www.sarft.gov.cn/art/2008/3/7/art_106_4477.html (accessed 22 January 2017).

'Zhonghua renmin gongheguo xingfa xiuzhengan (9)' [Criminal Law of the People's Republic of China Amendment (9)] (2015) Adopted by the Fifth Session of the Eighth National People's Congress on 14 March 1997 and amended by the Sixteenth Session of the Twelfth National People's Congress on 29 August 2015. Available at: http://epaper.legaldaily.com.cn/fzrb/content/20150905/Articel02002GN.htm (accessed 22 January 2017).

Zuigaorenminfayuan, zuigaorenminjianchayuan (1984) 'Zuigaorenminfayuan, zuigaorenminjianchayuan guanyu dangqian banli liumang anjianzhong juti yingyong falü de ruogan wenti de jieda' [Supreme People's Court and Supreme People's Procuratorate: answers on questions about the current handling of cases of hooliganism according to law], 2 November. Available at: 
Elaine Jeffreys (2018) 'Public Policy and LGBT People and Activism in Mainland China', in W. Lam (ed.) Routledge Handbook of the Chinese Communist Party, Abingdon: Routledge, pp. 283-96.

ISBN: 9781138684430. (Author Copy: 22 January 2017)

http://www.chinalawedu.com/news/1200/21994/22009/2006/3/li79920231013600214-0.htm (accessed 22 January 2017). 